\title{
Causes of the stage crisis in the early twentieth century Spain
}

\author{
José Salvador Blasco Magraner ${ }^{1}$, Francisco Carlos Bueno Camejo ${ }^{2}$ \\ ${ }^{1}$ Department of Music - University of Valencia - Valencia - Spain \\ ${ }^{2}$ Department of History of Art - University of Valencia - Valencia - Spain
}

Email address:

j.salvador.blasco@uv.es(J. S. B. Magraner), francisco.bueno@uv.es(F. C. B. Camejo)

\section{To cite this article:}

José Salvador Blasco Magraner, Francisco Carlos Bueno Camejo. Causes of the Stage Crisis in the Early Twentieth Century Spain. International Journal of Literature and Arts. Vol. 1, No. 1, 2013; pp. 7-10. doi: 10.11648/j.ijla.20130101.12

\begin{abstract}
During the nineteenth century, Spain experienced a turbulent political era, between monarchies, revolution and republic. This article analyzes the historical evolution of the "zarzuela" (Spanish popular opera, equally popular in Latin America) from the nineteenth century until the Second Spanish Republic, before World War II, explaining the causes of its decline in the twentieth century.
\end{abstract}

Keywords: Zarzuela, Spanish Popular Opera, Theater, Spanish Films, Vicente PeydrÓ, Ruperto ChapÍ

\section{Art Historical Background: The Turbulent Nineteenth Century}

The nineteenth century is an especially turbulent one in Spain: Napoleonic and civil wars, revolutions, coups d'État, six kings, a republic, the restoration, several constitutions, colonial wars and the loss of the colonies.

While these turbulent events were taking place, people regularly attended theatrical performances. The rise of Rossini's operas in Spanish theaters during the decade of 1820-1830 made the Italian opera invade those same theaters over the next twenty years. This situation continued until the period 1850-1860, in which Italian opera shared the stage with the mighty zarzuela.

The years of Isabel II's monarchy saw the predominance of a large zarzuela with European bouquet. There existed plenty of coloratura in song writing as a legacy from Italian bel canto opera (Rossini, Bellini, Donizeti) - from which Arrieta's "Marina" is a good sample.

After the Democratic Six-year period and the economic crisis over the last years of Isabel II's government, the music disappeared as a science and art in the Spanish educational system. From that moment on, the political and intellectual class and lawyers turned their backs on this phenomenon. ${ }^{1}$

1 CASARES RODICIO, E Y CELSA ALONSO, G.: La música española en el
The arrival of Alfonso XII Restoration saw the establishment of the "theater for hours", where for a similar price one could see and hear up to four lesser works in the "chico" genre, instead of a previous large three or four acts zarzuela that also mutated the setting and theme.

This new conception of the theatrical woks, following $\mathrm{M}^{\mathrm{a}}$ Pilar Espín point of view, had an effect not just on the spectators themselves but also and to a large extent, on the entrepreneurs (these were to organize the new marketing theatrical system because they could not charge the same amount of money for a full function than for another that lasted about forty-five minutes or an hour at the most), the authors, in turn, were in the need to reduce their work to a single act condensing all the theatrical action in what constituted a real display of memorized execution for the actors having to learn hundreds of small works with which they were able to delight the large crowd that they used to meet daily. ${ }^{2}$

We find ourselves now in a Madrid where newly built theaters (Lope de Vega, zarzuela, Variety) ${ }^{3}$ failed to cope

\footnotetext{
siglo XIX, Universidad de Oviedo Servicio de publicaciones, Oviedo, 1995, pág. 21.

2 ESPÍN TEMPLADO, M.P: El teatro por horas en Madrid (18701910).Subgéneros que comprende, autores principales y análisis de alguna sobras representativas, Madrid, Universidad Complutense de Madrid, 1988, pág. 63.

3 MUÑOZ, M: Historia de la zarzuela y el género chico, Madrid, Tesoro, 1945, pág. 234.
} 
with the huge demand for new shows due to high ticket prices and the rigidity of the timetable in which they were staged. $^{4}$

As the setting and theme also changed, regional manners were fostered by such literary movements such as the Valencian and Catalan Renaissance (Renaixença).

After the Revolution of September 1868 zarzuela became politicized and it introduced all kinds of criticism and satire to the Elizabethan regime. With the emergence of the "chico" genre, zarzuela regained its anecdotal and customs and manners appearance, as well as details of local color. $^{5}$

\section{The Twentieth Century}

In the late nineteenth century and early twentieth century, the situation was critical on the Spanish stage. Until then, theaters had harbored the most diverse activities, from the attractions of Micaela R. Alegría, drama and comedy companies, the psychaliptic genre, the operettas, operas and the entertainment of cinema. ${ }^{6}$

The decline of operatic activity, initiated in 1911, is especially evident from the 20s. The "Almanac" of Las Provincias newspaper describes the moment as "The dreadful crisis of theatrical productions". 7 The 20 s walked into a situation characterized by an international opera crisis:

"Before Ecilpse (which roughly corresponds to the period between the early 20s and the early postwar years), the opera had experienced periods of great success with large audiences." 8

Another reason involved in this crisis is the increasing importance and popularity of the cinema. The first Spanish film companies emerged in Catalonia. In 1897 the first Spanish film with a script appeared: Riña en UN Café ${ }^{9}$, by Fructuoso Gelabert. ${ }^{10}$

In the late nineteenth century, Barcelona was one of the most modern and industrialized cities in Spain. It owned a dynamic and prosperous bourgeoisie that from the very first

4MONTIJANO RUIZ, J.: Historia del Teatro olvidado: La Revista (1864-2009) Tesis Doctoral, Universidad de Granada, Granada, 2009, pág. 61.

5 BLASCO MAGRANER, J.S.: La zarzuela costumbrista, Cuadernos de Bellas Artes CABA/09, Universidad de La Laguna, La Laguna, 2012, pág. 16.

6 BLASCO MAGRANER, J.S y BUENO CAMEJO, F.C.: Radiografía del teatro musical, Cuadernos de Bellas Artes CABA/11, Universidad de La Laguna, La Laguna, 2013, pág. 15.

7 Almanaque de Las Provincias, 1923.

8 LEIBOWITZ, R.: Historia de la ópera. Taurus Humanidades. Madrid, 1990, pág. 12.

9 CAPARRÓS LERA, J. Ma.: Historia crítica del cine español (desde 1897 hasta hoy). Ariel, Barcelona, 1998, pág. 12.

10 Fructuoso Gelabert was the author of the first documentaries with an incipient narrative structure such as Salida de la iglesia de Santa Maria de Sants or Salida de los trabajadores de la fábrica "The Industrial Spain", both dated 1897. The first film company appears this year too, in Catalonia, founded by Segundo de Chomón and Marro Maraya, Segundo de Chomón worked with Méliès in France before this project which lasted until 1906.

With these first film companies the film market opened in Spain. moment felt a special attraction for cinema, and included also a large audience among the working class. Due to this the film entertainment had a greater success and prosperity elsewhere in Spain.

With the appearance of the first film companies linked to the film entertainment a whole new market related to cinema started in Spain. In 1906 the first great Spanish film company was created, the Hispanic-Films. After the creation of Hispanic Films it soon followed the construction of a network of movie theaters giving Spain a cinema infrastructure. The initial production was nevertheless handmade. The literary influence of the works in this period was notorious, though the Hispanic quaintness was exaggerated and sometimes they abused of false platitudes or clichés. ${ }^{11}$

The penetration of the cinema in theaters, against which the opera and zarzuela cannot compete as a show business due to their greater scarcity of means was one of the reasons involved in the stage crisis. Opportunistic or less ambitious entrepreneurs bet on this "invention" because the cinema sessions resulted in fewer organization and infrastructure problems, in addition to its relative newness. $^{12}$

In this sense, it is symptomatic the seasonal decline in the number of interpretations of opera and zarzuela in the Spanish theaters between the years 1900-1925. In the the Ruzafa Theater of Valencia, during the first years in which Patricio León, Vicente Peydró and Eduardo Senís were at the head of the company, the theatrical season used to begin during the first week of September but the start of the zarzuela season was delayed up well into October, due to the expansion of the cinema. For example, the 1906 season began on September 6, while the 1914 season began on October 8 .

The fever for the cinematographer also splashed the Teatro Principal of Valencia. The 1921-1922 theater seasons opened on October 7 and the cinematographer was the first show that was offered.

However, one cannot blame the cinematographer as solely responsible for the stage crisis in Spain at the time. The causes were diverse and complex. One of these main causes was the role played by entrepreneurs, artists and even the same authors, most of them guilty of the poor quality, low-birth tasteless eroticism of the works.

If we pay attention to the great composer Vicente Peydró:

"They're all at the same level! Entrepreneurs, artists, authors and the public are all the same. They are performing works that leave behind the worst works of cabarets and kursal showrooms. A "Sanatorium of Love"

11 BLASCO MAGRANER, J.S.: Vicente Peydró Díez y las primeras zarzuelas en el cine español: vida y obra de un músico valenciano. Cuadernos de Bellas Artes CABA/16, Universidad de La Laguna, La Laguna, 2013, págs. 333-334. 12 BUENO CAMEJO, F.C.: Historia de la ópera en Valencia y su representación según la crítica de arte: de la monarquía de Alfonso XIII a la guerra civil española, Tesis doctoral, Universitat de València, Valencia, 1997, pág. 40 . 
(how bizarre!) has been recently released. When the audience has applauded and has not set fire to the theater, it is because there is no longer a feeling of shame. "13

Among the entrepreneurs there were two distinct functions: the owners and the tenants. The first ones just kept an eye on those to whom they rented their theaters, ignoring at all times the quality offered by tenants in the opera and zarzuela performances that were represented in the scene. The tenants did not bother either in hiring companies with good programs and a minimum of pedigree. The criteria for hiring a certain company obeyed exclusively to economic factors rather than to any other kind. The tenants were experts in earning easy money. They were aware of the type of audience that often attended the shows, and did not hesitate to meet the desires of an uneducated public and eager public who was also eager to see ordinary erotic shows.

Businessmen and entrepreneurs were also moved by power and restricted themselves to ensure huge quantities of money, not worrying about the productions that were performed in theatrical venues. This was due to the ignorance of the vast majority of entrepreneurs to move in the theatrical and artistic boundaries, as many of them came from the most varied professions that had nothing to do with the world of the proscenium.

In this context, the theaters welcomed shows that were all the rage among the public, as the performances of the variety shows that replaced the world well-known celebrities (Rubinstein, Sarasate, Titta Rufo, Bottesini) who performed in these same theaters in past times.

Another of the musical circumstances or factors responsible for the crisis was theatrical singer's representatives or agents. Since the large blooming of the castrati in the eighteenth century, concerning baroque opera seria of a Metastasian model, the divos used to have a representative or agent. In this regard, it must be recalled how the representative of Carlo Broschi, Farinelli, was his own brother, also a composer: Riccardo Broschi. The representatives of the singers in the early twentieth century Spain were, in general, frustrated singers trying to make the most economical possible profit in the business. They got exorbitant wages and pushed to increase the number of opera functions without taking into account or bothering at all about the quality of the works. Moreover, as if it were not enough, all this caused that staged operas that were performed were made in haste and with few rehearsals.

The Actors Guild ("Sociedad de Actores") was the institution entrusted with watching over that the actors continued enjoying big salaries that choked everyday's business life. Likewise the institution allowed its explotation by unsuccessful artists that became entrepreneurs, business representatives and business

13 PEYDRÓ DÍEZ, V.: “Consideraciones sobre el estado actual del teatro”, En: Recuerdos de un músico viejo. Manuscrito sin datación, Biblioteca de Cataluña, MS. 2105). arrangers. $^{14}$

Another factor of great importance was related to stage pit musicians. During the monarchy of Alfonso XIII, the associate professors in the Ateneo Musical, offered highprofile obstructionist behaviors, such as the famous representation of Barbieri di Siviglia by Rossini on the occasion of the visit of the great soprano Elvira de Hidalgo, who years later became Maria Callas's teacher. The somewhat wayward character of the instrumentalists as well as their laziness and lack of commitment with their companies were the key obstacles to the normalization of these.

It must not be forgotten the role played by the Authors Guild acting with profit in the canons of theater property rights, while, by monopolizing the premieres, prevented the spreading of the works in the most popular theaters. The Authors Guild prevented the resurgence of a national opera, which in those days was so popular, and the consequences would reach the Second Spanish Republic, when the government of Don Manuel Azaña, in 1931, founded the famous Lyric Theatre National Board, in order to foster the creation of an indigenous lyrical production.

It is important to add the role played by the press and politicians. The press was prone to partial judgments, misleading the public opinion under the influence of friendships or the recommendations of the employers and the representatives. In this way, music reviews used not to be impartial and for this reason, the press was somewhat dishonest.

Concerning politicians it is necessary to say that they failed to ensure the behavior and the reputation of the shows. Governments did not encourage the creation of contests to reward scripts and musical scores, did not subsidize or gave financial aids to theaters, nor lowered the huge taxes and tributes that made life impossible for theaters and companies.

In fact, however, the most remarkable factor in the musical stage crisis in Spain was probably the lack of overall talent of contemporary Spanish composers. The golden age of opera in which every evening the successful premieres of works by Gaztambide, Barbieri, Arrieta and Caballero followed one another had disappeared long ago.

Then it came the illustrious names of Chapí and Breton. With La Tempestad, Chapí injected new blood to the zarzuela, lengthening at the same time the life of theater companies. With such titles as La Bruja and El Rey que Rabió, the great composer of Villena created the true Spanish operetta and paved the way to the "chico" genre. This latest and modest theater called "Theatre for hours" was maintained by the genius of composers like Chueca, Valverde, Rubio and Espino, undergoing a major transformation with Chapí, Caballero, Bretón and Nieto.

14 BLASCO MAGRANER, J.S y BUENO CAMEJO, F.C.: Radiografía del teatro musical, Cuadernos de Bellas Artes CABA/11, Universidad de $\mathrm{La}$ Laguna, La Laguna, 2013, Pág. 23. 
The path was even more tortuous for the great Breton due to his failed attempt to create a national theater through opera.

The last great generation of Spanish musicians that, guided by the lessons of their predecessors, were formed and got to give a new impetus to the zarzuela maintaining and bringing the last glimpses of light to the genre were Peydró, Lleó Serrano, Penella, Luna, Calleja, Barrera, Quislant and Foglietti. A brilliant chapter in the history of opera in Spain closes with them.

\section{References}

[1] BLASCO MAGRANER, J.S.: La zarzuela costumbrista, Cuadernos de Bellas Artes CABA/09, Universidad de La Laguna, La Laguna, 2012.

[2] BLASCO MAGRANER, J.S.: Vicente Peydró Díez y las primeras zarzuelas en el cine español: vida y obra de un músico valenciano. Cuadernos de Bellas Artes CABA/16, Universidad de La Laguna, La Laguna, 2013.

[3] BLASCO MAGRANER, J.S y BUENO CAMEJO, F.C.: Radiografía del teatro musical, Cuadernos de Bellas Artes
CABA/11, Universidad de La Laguna, La Laguna, 2013.

[4] BUENO CAMEJO, F.C.: Historia de la ópera en Valencia y su representación según la crítica de arte: de la monarquía de Alfonso XIII a la guerra civil española, Tesis Doctoral, Universitat de València, Valencia, 1997.

[5] CASARES RODICIO, E Y CELSA ALONSO, G.: La música española en el siglo XIX, Universidad de Oviedo Servicio de publicaciones, Oviedo, 1995.

[6] CAPARRÓS LERA, J. Mª: Historia crítica del cine español (desde 1897 hasta hoy). Ariel, Barcelona, 1998.

[7] ESPÍN TEMPLADO, M.P: El teatro por horas en Madrid (1870-1910).Subgéneros que comprende, autores principales y análisis de alguna sobras representativas, Universidad Complutense de Madrid, Madrid, 1988.

[8] LEIBOWITZ, R.: Historia de la ópera. Taurus Humanidades. Madrid, 1990.

[9] MONTIJANO RUIZ, J.: Historia del Teatro olvidado: La Revista (1864-2009), Tesis Doctoral, Universidad de Granada, Granada, 2009.

[10] MUÑOZ, MATILDE: Historia de la zarzuela y el género chico, Tesoro, Madrid, 1945. 